\title{
STUDI MINAT SISWA DALAM MENGIKUTI SENAM PAUD CERIA DI TK BINA ANA PRASA KECAMATAN BENOWO SURABAYA
}

\author{
Mira Pradipta Ariyanti \\ Program Studi Pendidikan Luar Sekolah Jurusan Ilmu Pendidikan \\ Fakultas Keguruan dan Ilmu Pendidikan STKIP BIM Surabaya \\ email:mira_ugiwaa@yahoo.co.id
}

Received February 2018, Accepted March 2018, Published April 2018

\begin{abstract}
Student Interest Study in Following Gymnastics Cheers In Bina Ana Prasa Kindergarten Sub Benowo Surabaya. The formulation of the problem in this research is how is the interest of students in following gymnastics early childhood at Bina Ana Prasa Kindergarten Benowo Surabaya? This study aims to find out what causes student interest in following gymnastics PAUD Ceria in kindergarten Bina Ana Prasa Benowo Subdistrict Surabaya. In this research used is the method of observation with the type of Descriptive research. The population in this study were all students who participated in PAUD Ceria gymnastics activity which amounted to 70 people and the samples used in this study were as many as 30 people conducted in total sampling that included all individuals or members of the population into a sample. There are some problems that researchers found that affect the interest of Bina Ana Prasa kindergarten students in following the Eccentric gymnastics and the problem is categorized as follows, namely the influence of self-desire to do gymnastics PAUD Ceria with $50 \%$ percentage, encouragement and support from sports teachers with 55 percentage $\%$, and the desire to do gymnastics PAUD Cheers for a friend with a percentage of $20 \%$, as well as eager to follow PAUD Ceria gymnastics out of school with a percentage of $60 \%$.
\end{abstract}

Keywords: Study, Interests, Gymnastics PAUD Ceria

\begin{abstract}
Abstrak: Studi Minat Siswa dalam Mengikuti Senam PAUD Ceria Di TK Bina Ana Prasa Kecamatan Benowo Surabaya. Rumusan masalah dalam penelitian ini adalah bagaimanakah minat siswa dalam mengikuti senam PAUD Ceria di TK Bina Ana Prasa Benowo Surabaya? Penelitian ini bertujuan untuk mengetahui apa yang menyebabkan minat siswa dalam mengikuti senam PAUD Ceria di TK Bina Ana Prasa Kecamatan Benowo Kota Surabaya. Dalam penelitiaan ini Metode yang digunakan adalah metode observasi dengan jenis penelitian Deskriptif. Populasi dalam penelitian ini adalah seluruh siswa yang mengikuti kegiatan senam PAUD Ceria yang berjumlah 70 orang dan sampel yang digunakan dalam penelitian ini adalah sebanyak 30 orang yang dilakukan secara total sampling yaitu mengikutsertakan semua individu atau anggota populasi menjadi sampel. Ada beberapa masalah yang ditemukan peneliti yang mempengaruhi minat siswa TK Bina Ana Prasa dalam mengikuti senam PAUD Ceria dan masalah tersebut dikategorikan sebagai berikut, yaitu pengaruh dari keinginan diri sendiri melakukan senam PAUD Ceria dengan presentase 50\%, dorongan dan dukungan dari guru olahraga dengan presentase 55\%, serta keinginan melakukan senam PAUD Ceria karena teman dengan presentase $20 \%$, serta berkeinginan mengikuti lomba senam PAUD Ceria di luar sekolah dengan presentase $60 \%$.
\end{abstract}

Kata Kunci : Studi, Minat, Senam PAUD Ceria

Dalam rangka pembangunan bangsa dan pembentukan manusia seutuhnya, maka olahraga mempunyai peranan yang sangat penting dalam mencapai usaha tersebut. Pembangunan yang kita laksanakan bertujuan untuk mewujudkan masyarakat Indonesia yang maju, sejahtera lahir dan batin, termasuk sehat jasmani dan rohani. Manusia yang sehat merupakan sumber daya yang dibutuhkan dalam pembangunan. Oleh karena itu, Pemerintah Indonesia melalui ketetapan MPRRI nomor II tahun 1983 dalam GBHN (Garis- garis Besar Haluan Negara) mengenai olahraga menetapkan olahraga perlu makin ditingkatkan dan dimasyarakatkan sebagai cara pembinaan jasmani dan rohani bagi setiap anggota masyarakat. Kemudian didukung pula oleh anjuran pemerintah dalam gerakan panji olahraga Nasional Tahun 1984 yaitu Memasyarakatkan olahraga dan Mengolahragakan Masyarakat. Maksud kalimat tersebut adalah memperkenalkan olahraga kepada masyarakat dengan cara mensosialisasikannya, bahwa olahraga itu sangat penting dan bermanfaat bagi kesehatan, 
Kemudian mengajak masyarakat untuk melaksanakan senam SKJ. Untuk merealisasi gerakan panji olahraga Nasional itu, depertemen pendidikan dan kebudayaan, bekerjasama dengan kantor menteri pemuda dan Olahraga telah menyusun suatu bentuk olahraga kesehatan untuk masyarakat yaitu dimulai dari senam pagi Indonesia (SPI) seri A, B, C dan D. Senam Kesegaran Jasmani (SKJ) 1984, 1988, sampai SKJ 1992. Senam Kesegran Jasmani diperkenalkan pada awal 1984 berdasarkan surat pemerintah Menpora untuk diajarkan keseluruh lapisan masyarakat. Tak tanggung-tanggung pemerintah menerapkan senam mulai dari tingkatan usia dini hingga dewasa. Dalam hal ini, tingkatan usia dini justru lebih penting untuk diberi latihan yang sesuai dengan kriteria anak usia dini. Maka dari itu diciptakan senam PAUD Ceria yang diciptakan khusus bagi anak usia dini. Penerapan senam PAUD ceria dilakukan melalui pelatihan-pelatihan yang dilakukan diberbagai lembaga.

Latihan senam PAUD Ceria apabila dilakukan secara teratur dan sistematis serta dengan memperhatikan prinsip-prinsip latihan, hasilnya akan berpengaruh bagi kesehatan dan kesegaran jasmani. Direkorat keolahragaan depertemen pendidikan dan kebudayaan (1985: 18) menyatakan manfaat senam PAUD ceria yaitu apabila gerakan senam PAUD Ceria ini secara keseluruhan dan dengan dosis atau takaran tertentu, sudah dapat dipastikan bahwa kesehatan dan kesegaran jasmani pelakunya akan lebih meningkat, sehingga pembangunan bangsa yang kita dambakan akan lebih terjamin.

Senam PAUD Ceria yaitu senam yang diwajibkan oleh pemerintah Indonesia untuk anak usia dini. Senam ini biasanya diiringi oleh lagu berirama dari berbagai propinsi yang diaransemen ulang dan biasanya yang dilakukan oleh sekolompok anak-anak. Pada saat ini kita dapat melihat di sekolahsekolah yang ada di daerah kita khususnya di Surabaya bagian barat, pada setiap hari jumat pagi murid-murid di sekolah tersebut melakukan aktivitas yaitu senam bersama, tetapi kita ketahui bersama bahwa ada beberapa sebagian siswa kurang atau jarang mengikuti senam PAUD Ceria disekolah. Seperti di TK Bina Ana Prasa, setelah peneliti melakukan observasi ada beberapa sebagian siswa kurang atau jarang melakukan senam PAUD Ceria yang dilakukan setiap Jumat paginya. Ini dikarenakan sebagian siswa masih kurang atau belum memahami manfaat dan tujuan melakukan senam PAUD Ceria. Oleh sebab itu, maka peneliti tertarik dan bermaksud untuk melakukan penelitian tentang Studi minat siswa dalam mengikuti senam PAUD Ceria di TK Bina Ana Prasa Kecamatan Benowo Kota Surabaya.

Berdasarkan latar fenomena yang menjadi rumusan masalah pada penelitian ini adalah bagaimana minat siswa dalam mengikuti senam PAUD Ceria di TK Bina Ana Prasa Kecamatan Benowo Kota Surabaya? Adapun tujuan penelitian yaitu untuk mengetahui minat siswa dalam mengikuti senam PAUD Ceria di TK Bina Ana Prasa Kecamatan Benowo Kota Surabaya.

\section{METODE}

Pendekatan ini menggunakan pendekatan kualitatif, pendekatan kualitatif merupakan pendekatan yang dilakukan dalam situasi yang wajar (natural setting) dan data yang dikumpulkan bersifat kualitatif. Penelitian kualitatif adalah penelitian yang berusaha menjelaskan secara mendalam tentang semua apa yang penelitian analisis adalah pendekatan yang berusaha memahami gagasan, cara dan sikap pengarang dalam menampilkan gagasannya serta keterkaitan setiap elemen intrinsik sehingga mampu membangun adanya keselarasan dan kesatuan bentuk dan maknanya (Suhendar dan Supiah, 1993 : 40).

Selain itu, instrument adalah si peneliti sendiri. Peneliti merupakan key instrument, yakni peneliti harus terjun sendiri kelapangan secara aktif (Usman, 2004: 81) dan dipertegas lagi oleh Nasution dalam (Sugiyono, 2010 : 223) dalam penelitian kualitatif tidak ada pilihan lain dari pada menjadikan manusia sebagai instrument penelitian utama. Alasannya, segala sesuatu belum mempunyai bentuk yang pasti. Masalah, fokus penelitian, hipotesis yang digunakan, bahkan hasil yang diharapkan, itu semua tidak dapat ditentukan secara pasti dan jelas sebelumnnya. Dalam keadaan yang serba tidak pasti dan jelas itu, tidak ada pilihan lain dan hannya peneliti itu 
58 Jurnal PG-PAUD Trunojoyo : Jurnal Pendidikan dan Pembelajaran Anak Usia Dini, Volume 5, Nomor 1, April 2018, hal 56 - 63

sendiri sebagai alat satusatunya yang dapat mencapainya.

Rancangan Penelitian ini meliputi:

\section{Sumber Data}

Sumbar data dalam penelitian ini adalah Penelitian Observasi yaitu peningkatan siswa dalam mengikuti senam PAUD Ceria di TK Bina Ana Prasa Kecamatan Benowo Kota Surabaya. Dengan jumlah populasi sebanyak 70 orang dengan sampel sebanyak 30 orang dengan tehnik total sampling yakni mengikut sertakan semua individu atau anggota populasi menjadi sampel.

2. Lokasi Penelitian

Penelitian ini dilaksanakan di Sekolah TK Bina Ana Prasa Kecamatan Benowo Kota Surabaya.

Teknik pengumpulan data merupakan langkah yang paling strategis dalam penelitian, karena tujuan utama dari penelitian adalah mendapatkan data. Tanpa mengetahui teknik pengumpulan data, maka peneliti tidak akan mendapatkan data yang memenuhi standar data yang ditetapkan. Teknik pengumpulan data dalam penelitian ini dengan menggunakan metode angket atau kuesioner sederhana. Kuesioner merupakan teknik pengumpulan data yang dilakukan memberi seperangkat pernyataan atau pernyataan tertulis kepada responden untuk dijawabnya. Kuesioner merupakan tehnik pengumpulan data yang efisien bila peneliti tau dengan pasti variabel yang akan diukur dan tau apa yang bisa diharapkan dari responden (sugiono, 2010:199). Metode angket atau kuesioner adalah sejumlah pertanyaan tertulis yang digunakan untuk memperoleh informasi dari responden dalam arti laporan tentang pribadinya, atau hal-hal yang ia ketahui (Arikunto, 1998:128). Metode angket dalam penelitian ini adalah metode angket langsung tertutup yaitu responden menjawab semua pertanyaan yang telah disediakan dilembar soal dengan menggunakan pilihan ganda dengan jumlah angket 12 nomor. Dalam penelitian ini langkah-langkah yang dilakukan peneliti sebagai berikut:

1. Tahap persiapan

\section{a. Mencari Literature}

b. Menyusun instrumen yang digunakan dalam penelitian

c. Menyusun proposal penelitian

2. Tahap pelaksanaan

a. Menentukan lokasi, populasi dan sampel penelitian

b. Menyebarkan angket

3. Tahap akhir

Kegiatan yang dilakukan pada tahap akhir ini adalah pengumpulan data, pengolahan data, dan analisis data. Observasi adalah suatu tehnik untuk mengamati secara langsung maupun tidak langsung gejala-gejala yang sedang berlangsung baik di dalam sekolah maupun di luar sekolah (Djumhur, 1985: 51). Nasutian (Sugiyono, 2010: 403) menyatakan bahwa observasi adalah dasar semua ilmu pengetahuan. Para ilmuan hanya dapat bekerja berdasarkan data, yaitu fakta mengenai dunia kenyataan yang diperoleh melalui observasi. Observasi merupakan suatu penelitian yang secara sistematis menggunakan kemampuan indera manusia. Pengamatan dilakukan pada saat terjadi kegiatan senam PAUD Ceria. Dokumen merupakan catatan peristiwa yang sudah berlalu. Dokumen bisa berbentuk tulisan, gambar, atau karyakarya monumental dari seseorang (Sugiyono, 2010 : 422). Dokumen yang berbentuk tulisan misalnya catatan harian, sejarah kehidupan (life histories) cerita, biografi, peraturan kebijakan. Dokumen yang berbentuk gambar, misalnya foto, gambar hidup, sketsa dan lain-lain. Pengertian dokumentasi dalam kamus besar bahasa Indonesia didefinisikan sebagai suatu tertulis, tercetak yang dipakai sebagai bukti atau keterangan. Analisis Data Mengacu pada jenis penelitian maka data yang diperoleh akan dianalisis dengan menggunakan pendekatan deskriptif- kualitatif, dimana memberikan gambaran tentang minat siswa dalam mengikuti senam PAUD Ceria, setelah semua data terkumpul, langkah selanjunya menganalisis data sehingga dapat menarik kesimpulan 
melalui perhitungan sebagai berikut. Menurut Arikunto (1998 : 245-246) Bahwa tehnik perhitungan dalam angket menggunakan presentase yang kemudian ditafsirkan kedalam bentuk kalimat yang menggambarkan kuantitas dari data tersebut. Hal ini dapat menggambarkan studi minat siswa dalam mengikuti senam PAUD Ceria di TK Bina Ana Prasa Kecamatan Benowo Kota Surabaya. Tehnik analisis data mencari besarnya frekuensi relatife dengan menggunakan rumus berikut:

$$
\begin{aligned}
& \qquad \mathrm{P}=\mathrm{F} / \mathrm{N} \times 100 \% \\
& \text { Keterangan : } \\
& \mathrm{N}=\text { Jumlah frekuensi/jumlah anak didik } \\
& \mathrm{F}=\text { Frekuensi jawaban anak didik } \\
& \mathrm{P}=\text { Angka presentase }
\end{aligned}
$$

Pendekatan ini menggunakan pendekatan kualitatif, pendekatan kualitatif merupakan pendekatan yang dilakukan dalam situasi yang wajar (natural setting) dan data yang dikumpulkan bersifat kualitatif. Penelitian kualitatif adalah penelitian yang berusaha menjelaskan secara mendalam tentang semua apa yang penelitian analisis adalah pendekatan yang berusaha memahami gagasan, cara dan sikap pengarang dalam menampilkan gagasannya serta keterkaitan setiap elemen intrinsik sehingga mampu membangun adanya keselarasan dan kesatuan bentuk dan maknanya (Suhendar dan Supiah, 1993 : 40).

\section{HASIL DAN PEMBAHASAN}

Penelitian ini mendeskripsikan atau memberikan gambaran tentang minat siswa dalam mengikuti Senam PAUD Ceria di TK Bina Ana Prasa Kecamatan Benowo Kota Surabaya. Berdasarkan analisis data yang dilakukan oleh peneliti yang menggunakan angket atau kuesioner sebagai berikut:

1. Deskripsi minat siswa dalam mengikuti Senam PAUD Ceria setiap Jumat pagi serta penjelasan tentang manfaat senam PAUD Ceria. Dari hasil penelitian tersebut siswa sangat senang mengikuti kegiatan senam PAUD Ceria setiap jum'at pagi. dari 30 responden dengan 12 butir soal diberikan, yang senang mengikuti Senam PAUD Ceria setiap jum'at pagi. Dari data tersebut 20 orang siswa atau $80 \%$ setuju, 10 orang atau $20 \%$ sangat setuju melakukan senam PAUD Ceria setiap jumat paginya. Sedangkan siswa yang tidak setuju dan kurang setuju tdak ada atau 0\%. Untuk mengikuti senam PAUD Ceria tiap jum'at paginya. Pada dasarnya siswa senang dengan hal-hal yang menarik dan ingin melakukannya. Begitu pula dengan penjelasan guru olahraga tentang manfaat senam PAUD Ceria dari hasil penelitian menunjukan siswa yang menjawab setuju 20 orang atau $80 \%$, siswa yang menjawab sangat setuju 10 orang atau $20 \%$, sedangkan yang menjawab tidak setuju dan kurang setuju tidak ada atau $0 \%$, yang tidak senang bila guru olahraga menjelaskan manfaat senam PAUD Ceria.

2. Deskripsi minat siswa tentang guru olahraga menjadi instruktur senam PAUD Ceria dan rajin mengikuti kegiatan senam PAUD Ceria. Hasil penelitian menunjukan siswa yang menjawab setuju 12 orang atau $16 \%$, siswa yang menjawab sangat setuju 15 orang atau $60 \%$ senang kalau guru olahraga menjadi instruktur senam, sedangkan siswa yang menjawab tidak setuju tidak ada atau $0 \%$, siswa yang menjawab kurang setuju 2 orang atau $26 \%$ yang tidak senang bahwa guru olahraganya menjadi instruktur senam PAUD Ceria. Dari hasil data tersebut siswa senang bila selalu dibimbing dalam proses belajar. Hasil penelitian menunjukan bahwa siswa yang menjawab setuju 12 orang atau $35 \%, 18$ orang atau $65 \%$ siswa yang menjawab sangat setuju bila guru olahraga rajin dan aktif mengikuti senam PAUD Ceria. Sedangkan yang menjawab tidak setuju dan kurang setuju tidak ada yang memilih atau 0\%. Dari hasil tersebut sudah jelas bahwa siswa yang senang bila guru olahraganya menjadi instruktur senam lebih banyak dari pada siswa yang tidak setuju atau kurang setuju bila guru olahraganya menjadi instruktur senam tersebut.

3. Deskripsi tentang apakah siswa senang bila selain guru olahraga, guru-guru yang 
60 Jurnal PG-PAUD Trunojoyo : Jurnal Pendidikan dan Pembelajaran Anak Usia Dini, Volume 5, Nomor 1, April 2018, hal 56 - 63

lain ikut serta dalam melakukan kegiatan senam PAUD Ceria. Hasil penelitian menunjukan dimana siswa yang menjawab setuju 14 orang atau $35 \%$, siswa yang menjawab sangat setuju 15 orang atau $60 \%$, bila guru-guru lain selain guru olahraga ikut dalam kegiatan senam PAUD Ceria. Sedangkan siswa yang menjawab tidak setuju 1 orang atau $5 \%$, dan siswa menjawab kurang setuju tidak ada atau 0\%. Jadi bisa kita deskripsikan bahwa siswa senang bila selain guru olahraga, guru-guru lain ikut dalam kegiatan senam PAUD Ceria.

4. Deskiripsi tentang bila guru olahraga mengulangi senam 2 sampai 3 kali dan bila ada teman siswa lainnya tidak mengikuti senam PAUD Ceria. Seperti pada umumnya di sekolah dalam kegiatan senam PAUD Ceria, senam diulang lebih dari 1 kali dan ada siswa yang senang dan tidak senang dalam kegiatan tersebut. Hasil penelitian menunjukan bahwa siswa yang menjawab setuju 11 orang atau $22 \%$, siswa yang menjawab sangat setuju 15 orang atau $60 \%$ yang senang bila guru olahraga mengulangi senam 2 sampai 3 kali, sedangkan siswa yang menjawab tidak setuju 2 orang atau $9 \%$, dan siswa yang menjawab kurang setuju 2 orang atau $9 \%$ yang tidak senang dengan kegiatan tersebut, kemudian selanjutnya pada tabel 7 kita bisa lihat bahwa yang senang bila teman siswa lainnya tidak melakukan senam PAUD Ceria, siswa yang menjawab setuju 11 orang atau $8 \%$, siswa yang menjawab sangat setuju 2 orang atau $4 \%$, sedangkan yang tidak senang bila temannya tidak mengikuti senam yakni siswa yang menjawab tidak setuju berjumlah 20 orang atau $80 \%$, dan siswa yang menjawab kurang setuju 11 orang atau $8 \%$.

5. Deskripsi tentang siswa senang melakukan senam PAUD Ceria di luar sekolah dan bila guru olahraga tidak dapat mempraktikan gerakan senam PAUD Ceria. Dalam lingkungan sekolah siswa dituntut harus bisa melakukan kegiatan senam PAUD Ceria. Hasil penelitian menunjkan bahwa siswa yang menjawab setuju 12 orang atau $45 \%$, siswa yang menjawab sangat setuju 8 orang atau $25 \%$, yang senang melakukan kegiatan senam
PAUD Ceria di luar sekolah, sedangkan siswa yang menjawab tidak setuju 5 orang atau $15 \%$, dan siswa yang menjawab kurang setuju 5 orang atau $15 \%$ tidak senang melakukan kegiatan tersebut di luar sekolah. Hasil penelitian menunjukan siswa yang senang bila guru olahraganya tidak bisa mempraktikan kegiatan senam PAUD Ceria siswa yang menjawab setuju 2 orang atau $8 \%$, siswa yang menjawab sangat setuju 6 orang atau $24 \%$, sedangkan siswa yang menjawab tidak setuju 18 orang atau $52 \%$ dan siswa yang menjawab kurang setuju 4 orang atau $16 \%$ yang tidak senang bila guru olahraganya tidak bisa mempraktikan senam PAUD Ceria.

6. Deskripsi siswa senang melakukan olahraga lain, selain olahraga senam PAUD Ceria. Pada umumnya anak-anak senang melakukan berbagai olahraga yang ia sukai. Hasil penelitian menunjukan siswa yang menjawab setuju 6 orang atau $12 \%$, siswa yang menjawab sangat setuju 10 orang atau $50 \%$ yang senang melakukan senam PAUD Ceria selain olahraga lain, sedangkan siswa yang menjawab tidak setuju 8 orang atau $26 \%$ dan siswa yang menjawab kurang setuju 6 orang atau $12 \%$ yang tdak senang dengan mengikuti olahraga lain selain olahraga tersebut.

7. Deskripsi tentang siswa senang melakukan senam PAUD Ceria karena guru olahraga dan melakukan senam PAUD Ceria di sekolah serta senang bila guru olahraganya berhalangan hadir di sekolah. Pada umumnya anak-anak senang melakukan sesuatu kegiatan atau aktifitas karena lingkungan dan orang-orang yang ia senangi, hasil penelitian menunjukan bahwa siswa yang menjawab setuju 9 orang atau $26 \%$, siswa yang menjawab sangat setuju 13 orang atau $34 \%$ senang melakukan senam PAUD Ceria karena guru olahraga, sedangkan siswa yang menjawab tidak setuju 4 orang atau $20 \%$, dan siswa yang menjawab kurang setuju 4 orang atau $20 \%$ yang tidak senang melakukan senam PAUD Ceria karena guru olahraganya. Hasil penelitian menunjukan siswa yang menjawab setuju 3 orang atau $23 \%$, siswa yang menjawab sangat setuju 1 orang atau $10 \%$ yang tidak senang melakukan senam di sekolah, 
sedangkan siswa yang senang melakukan senam disekolah, siswa yang menjawab tidak setuju 23 orang atau $44 \%$, dan siswa yang menjawab kurang setuju 3 orang atau $23 \%$. Seperti yang kita lihat bahwa siswa yang menjawab setuju 1 orang atau $6 \%$, siswa yang menjawab sangat setuju 2 orang atau $15 \%$ yang senang bila guru olahraganya berhalangan hadir ke sekolah, sedangkan siswa yang menjawab tidak setuju 21 orang atau $44 \%$, dan siswa yang menjawab kurang setuju 6 orang atau $30 \%$ yang tidak senang bila guru olahraganya tidak hadir di sekolah.

8. Deskripsi siswa senang bila guru olahraganya memperhatikan gerakan senamnya dan siswa bertanya tentang manfaat melakukan senam PAUD Ceria serta melakukan senam PAUD Ceria karena teman. Hasil penelitian menunjukan bahwa siswa yang menjawab setuju 12 orang atau $40 \%$, siswa yang menjawab sangat setuju 17 orang atau $47 \%$ senang bila guru olahraganya memperhatikan gerakan senamnya, sedangkan siswa yang menjawab tidak setuju 1 orang atau $14 \%$ dan siswa yang menjawab kurang setuju tidak ada atau $0 \%$. Siswa yang menjawab setuju 16 orang atau $36 \%$, siswa yang menjawab sangat setuju 16 orang atau $32 \%$ yang senang bertanya tentang manfaat senam, dan siswa yang menjawab tidak setuju 1 orang atau $5 \%$, siswa yang menjawab kurang setuju tidak ada atau $0 \%$. Kemudian pada tabel 16. Siswa yang menjawab setuju 3 orang atau $9 \%$, dan siswa yang menjawab sangat setuju 13 orang atau $41 \%$ yang senang melakukan senam PAUD Ceria karena temannya, sedangkan siswa yang menjawab tidak setuju 10 orang atau $30 \%$ dan siswa yang menjawab kurang setuju 4 orang atau $20 \%$ yang tidak senang melakukan senam karena teman.

9. Deskripsi tentang guru olahraga selalu memberikan latihan senam PAUD Ceria untuk persiapan lomba dan memberikan penjelasan tentang manfaat senam bagi tubuh serta bila pada saat melakukan senam siswa yang salah gerakannya, guru olahraga membenarkan gerakan senam yang salah tersebut. Pada umumnya, sebuah kegiatan yang dilakukan harus disertai dengan latihan yang rutin sehingga menghasilkan hasil yang di inginkan serta mengetahui tujuan dan manfaatnya. Bahwa siswa yang menjawab setuju 15 atau $50 \%$, siswa yang menjawab sangat setuju 14 orang atau $45 \%$ bahwa guru olahraga memberikan latihan untuk persiapan lomba, sedangkan yang menjawab tidak setuju 1 orang atau $5 \%$ bahwa guru olahraganya tidak memberikan latihan senam, dan yang menjawab kurang setuju tidak ada atau $0 \%$. Hasil penelitian menunjukan siswa yang menjawab setuju 20 orang atau $60 \%$, siswa yang menjawab sangat setuju 10 orang atau $30 \%$, bahwa guru olahraga memberikan penjelasan manfaat senam bagi tubuh, sedangkan yang menjawab tidak setuju dan kurang setuju tidak ada atau 0\%. Hasil penelitian menunjukan bahwa siswa yang menjawab setuju 20 orang atau $65 \%$, siswa yang menjawab sangat setuju 9 orang atau

$25 \%$ bahwa bila gerakan senam siswa salah guru olahraga membenarkan gerakan senam tersebut, sedangkan yang menjawab tidak setuju 1 orang atau $10 \%$, dan siswa yang menjawab kurang setuju tidak ada atau $0 \%$.

10. Deskripsi tentang guru olahraga menerapkan bahwa senam PAUD Ceria dilakukan pukul 12 siang dan pada saat melakukan senam tersebut ada siswa atau murid yang jatuh pingsan serta adakah siswa yang tidak suka melakukan senam PAUD Ceria. Seperti yang telah kita ketahui bersama, bahwa disetiap sekolahsekolah pada umumnya, dalam kegiatan senam PAUD Ceria dilakukan setiap jumat paginya dan dilaksanakan pada pagi hari. Siswa yang menjawab setuju 2 orang atau $10 \%$, siswa yang menjawab sangat setuju 3 orang atau $20 \%$, bahwa guru olahraga menganjurkan senam pada pukul 12 siang, sedangkan siswa yang menjawab tidak setuju 22 orang atau $50 \%$, dan siswa yang menjawab kurang setuju 3 orang atau $20 \%$, menyatakan bahwa guru olahraga tidak menerapkan senam PAUD Ceria dilakukan pada pukul 12 siang. Hasil penelitian menunjukan bahwa siswa yang menjawab setuju 5 orang atau $15 \%$, siswa yang menjawab sangat setuju 5 orang atau $15 \%$ menyatakan bahwa pada saat melakukan senam ada siswa yang jatuh pingsan, dan 
62 Jurnal PG-PAUD Trunojoyo : Jurnal Pendidikan dan Pembelajaran Anak Usia Dini, Volume 5,

Nomor 1, April 2018, hal 56 - 63

siswa yang menjawab tidak setuju 15 orang atau $55 \%$, siswa yang menjawab kurang setuju 5 orang atau $15 \%$ yang menyatakan bahwa siswa pada saat melakukan senam tidak ada yang mengalami hal tersebut. Hasil penelitian menunjukan bahwa siswa yang menjawab setuju 7 orang atau $25 \%$, siswa yang menjawab sangat setuju 1 orang atau $10 \%$ bahwa tidak suka melakukan senam PAUD Ceria, sedangkan siswa yang menjawan tidak setuju 15 orang atau $40 \%$, dan siswa yang menjawab kurang setuju 7 orang atau $25 \%$ yang suka melakukan senam PAUD

Ceria tersebut.

11. Deskripsi tentang pada saat sebelum melakukan senam guru olah raga memberikan arahan terlebih dahulu sebelum melakukan senam PAUD Ceria dan guru olahraga selalu datang cepat ke sekolah untuk mengatur siswa dalam melakukan senam PAUD Ceria. Pada dasarnya anak-anak selalu menuruti apa yang gurunya katakan dan selalu mendengarkannya. Siswa yang menjawab setuju 20 orang atau $50 \%$, siswa yang menjawab sangat setuju 6 orang atau $30 \%$ menyatakan bahwa guru olahraga selalu memberikan arahan sebelum melakukan senam PAUD Ceria, sedangkan siswa yang menjawab tidak setuju 4 orang atau $20 \%$, siswa yang menjwab kurang setuju tidak ada atau $0 \%$ yang menyatakan bahwa guru olahraga tidak memberikan arahan sebelum melakukuan senam tersebut. Siswa yang menjawab setuju 17 orang atau $51 \%$, siswa yang menjawab sangat setuju 9 orang atau $28 \%$ menyatakan bahwa guru olahraga selalu dating cepat ke sekolah dalam mengatur siswa sebelum melakukan senam, sedangkan yang menjawab tidak setuju 3 orang atau $16 \%$, dan siswa yang menjawab kurang setuju 1 orang atau $5 \%$ yang menyatakan bahwa guru olahraga tidak selalu datang cepat ke sekolah dalam hal tersebut.

Deskripsi siswa senang dan bersungguh-sungguh melakukan senam PAUD Ceria. Hasil penelitian menunjukan siswa yang menjawab setuju 12 orang atau $35 \%$, siswa yang menjawab sangat setuju 17 orang atau $55 \%$, senang dan bersungguh-sungguh mengikuti kegiatan senam PAUD Ceria, sedangkan siswa yang menjawab tidak setuju 1 orang atau $10 \%$, dan siswa yang menjawab kurang setuju tidak ada atau $0 \%$, yang tidak senang dan bersungguh-sungguh melakukan senam PAUD Ceria.

\section{SIMPULAN}

Berdasarkan pembahasan hasil penelitian, maka simpulan dari penelitian ini sebagai berikut :

1. Minat siswa TK Bina Ana Prasa Kecamatan Benowo Kota Surabaya dalam melakukan senam PAUD Ceria dari faktor kemauan diri sendiri sekitar $65 \%$ sangat berminat melakukan senam tersebut, dan dari faktor melakukan senam PAUD Ceria karena orang lain sekitar $35 \%$.

2. Siswa TK Bina Ana Prasa sangat senang bila melakukan senam PAUD Ceria dibimbing dan diarahkan oleh guru olahraga.

\section{DAFTAR PUSTAKA}

Abror, A. R. (1998). Psikologi Pendidikan. Yogyakarta : Tiara Wacana

Arikunto, S. (1993). Prosedur Penelitian. Jakarta : Bina Aksara

Djamarah. (2000). Guru Dan Anak Didik Dalam Interaksi Edukatif. Jakarta: Rineka Cipta

Effendi. (1985). Pengantar Psikologi. Bandung: Pn. Transip

Hurlock, E. B. (1993). Perkembangan Anak Jilid 2. Jakarta: Erlangga

Erminawati. (2009). Kebugaran dan Kesehatan. Jakarta : Rikardo GBHN. TAP-TAP MPR No. 11/MPR/1993. Pidato Pertanggung Jawaban Presiden/Mandataris. Jakarta: Dirjen Dikti

Usman, B. dkk. (2005). Pedoman Menyusun dan Penilaian Karya Ilmiah. Palu: FKIP Untad

Agusta, H. (2009). Pola Gerak Dalam Senam. Jakarta : Penerbit CV. Ipa Abong

Nasir, M. (1988). Metode Penelitian. Jakarta: Ghalia 
Jurnal PG-PAUD Trunojoyo : Jurnal Pendidikan dan Pembelajaran Anak Usia Dini, Volume 5, Nomor 1,

Slameto. (1995). Belajar dan Faktor-Faktor yang Mempengaruhinya. Jakarta: Rineka Cipta

Sugiono. (2010). Metode Penelitian Bisnis. Bandung : Alfabeta

Arikunto, S. (1996). Prosedur Penelitian Survei Pendekatan Praktek. Jakarta : Rineka Cipta

Sukardi. (1987). Bimbingan Belajar di Sekolahsekolah. Jakarta : Ghalia Indonesia . 1993. Analisis Inventori Minat dan Kepribadian. Jakarta : Rineka Cipta

Sukardi, D. K. (1994). Perkembangan Minat. Jakarta : Bumi Aksara

Nurkancana, W. dan Sumartana. (1982). Evaluasi Pendidikan. Surabaya: Usaha Nasional 